\title{
BMJ Open Searching for a link between the L-BMAA neurotoxin and amyotrophic lateral sclerosis: a study protocol of the French BMAALS programme
}

\author{
Aurélie Delzor, ${ }^{1,2}$ Philippe Couratier, ${ }^{1,2,3}$ Farid Boumédiène, ${ }^{1,2}$ Marie Nicol, ${ }^{1,2,3}$ \\ Michel Druet-Cabanac, ${ }^{1,2,3}$ François Paraf, ${ }^{3}$ Annick Méjean, ${ }^{4}$ Olivier Ploux, ${ }^{4}$ \\ Jean-Philippe Leleu, ${ }^{1,2}$ Luc Brient, ${ }^{5}$ Marion Lengronne, ${ }^{5}$ Valérie Pichon, ${ }^{6,7}$ \\ Audrey Combès, ${ }^{6,7}$ Saïda El Abdellaoui, ${ }^{6,7}$ Vincent Bonneterre, ${ }^{8}$ \\ Emmeline Lagrange, ${ }^{9}$ Gérard Besson, ${ }^{9}$ Dominique J Bicout, ${ }^{8,10}$ Jean Boutonnat, ${ }^{9}$ \\ William Camu, ${ }^{11,12}$ Nicolas Pageot, ${ }^{11,12}$ Raul Juntas-Morales, ${ }^{11,12}$ \\ Valérie Rigau, ${ }^{11,12}$ Estelle Masseret, ${ }^{13}$ Eric Abadie, ${ }^{14}$ Pierre-Marie Preux, ${ }^{1,2,3}$ \\ Benoît Marin ${ }^{1,2}$
}

To cite: Delzor A, Couratier P, Boumédiène $\mathrm{F}$, et al. Searching for a link between the L-BMAA neurotoxin and amyotrophic lateral sclerosis: a study protocol of the French BMAALS programme. BMJ Open 2014;4:e005528. doi:10.1136/bmjopen-2014005528

- Prepublication history for this paper is available online To view these files please visit the journal online (http://dx.doi.org/10.1136/ bmjopen-2014-005528).

Received 22 April 2014 Revised 11 August 2014 Accepted 12 August 2014

CrossMark

For numbered affiliations see end of article.

Correspondence to Prof. Philippe Couratier; philippe.couratier@unilim.fr

\section{ABSTRACT}

Introduction: Amyotrophic lateral sclerosis (ALS) is the most common motor neurone disease. It occurs in two forms: (1) familial cases, for which several genes have been identified and (2) sporadic cases, for which various hypotheses have been formulated. Notably, the $\beta$-N-methylamino-L-alanine (L-BMAA) toxin has been postulated to be involved in the occurrence of sporadic ALS. The objective of the French BMAALS programme is to study the putative link between L-BMAA and ALS.

Methods and analysis: The programme covers the period from 1 January 2003 to 31 December 2011. Using multiple sources of ascertainment, all the incident ALS cases diagnosed during this period in the area under study (10 counties spread over three French regions) were collected. First, the standardised incidence ratio will be calculated for each municipality under concern. Then, by applying spatial clustering techniques, overincidence and underincidence zones of ALS will be sought. A casecontrol study, in the subpopulation living in the identified areas, will gather information about patients' occupations, leisure activities and lifestyle habits in order to assess potential risk factors to which they are or have been exposed. Specimens of drinking water, food and biological material (brain tissue) will be examined to assess the presence of $\mathrm{L}$ BMAA in the environment and tissues of ALS cases and controls.

Ethics and dissemination: The study has been reviewed and approved by the French ethical committee of the CPP SOOM IV (Comite de Protection des Personnes Sud-Ouest \& Outre-Mer IV). The results will be published in peer-reviewed journals and presented at national and international conferences.

\section{Strengths and limitations of this study}

- This is the first ambitious project to investigate the link between $\beta$ - $N$-methylamino-L-alanine (L-BMAA) and amyotrophic lateral sclerosis (ALS) in France, taking advantage of the existing federation of BMAALS consortium members in the French network on ALS clusters detection and investigation.

- The case ascertainment relies on multiple sources and, among those, on a common database shared by all French ALS referral centres, which collects information about patients since 2003. The study represents more than 47 million persons-years of follow-up.

- We developed and validated a new analytical procedure for the determination of underivatised L-BMAA at trace levels in complex environmental matrices.

- The rapid death of patients led to a major difficulty in finding living patients for questionnaires: patients' relatives are interviewed, which can induce a bias in responses.

- At the time of the writing, few patients have given their consent to a postmortem swab which can limit the impact of our study.

\section{INTRODUCTION}

Amyotrophic lateral sclerosis (ALS) is a debilitating and fatal neuromuscular disease with an incidence close to 2.5/100 000 person-years of follow-up (PYFU) in Europe. ${ }^{1}$ Two forms of the pathology coexist: familial ALS (FALS) accounts for approximately $10 \%$ of total cases and the remaining $90 \%$ occur sporadically (SALS, sporadic ALS). 
Historically, an association has been observed between a mutation on the superoxide dismutase 1 gene (SOD1) and FALS. ${ }^{2}$ However, other mutations ${ }^{3-8}$ have since been discovered, as C9orf72 (chromosome 9 open reading frame 72), TARDBP (TDP-43 encoding gene) and FUS (fused in sarcoma protein) are commonly identified in FALS cases. ${ }^{8-16}$

Although SOD1, FUS and TARDBP mutations have also been found in SALS cases, ${ }^{2} 17$ the current broad scientific consensus is in favour of a gene-environment interaction causing SALS: lifestyle factors, environmental exposure, occupational exposure and handling toxic compounds are among the many factors that can play a role in the appearance of the pathology. Among lifestyle factors, smoking is the factor that has been most documented and is mainly associated with a higher risk of ALS, ${ }^{18-23}$ whereas coffee and alcohol consumption are considered protective or not associated with ALS. ${ }^{18} 2425$ Other associations have been proposed as occupational exposure to electromagnetic fields, ${ }^{23}{ }^{26-29}$ frequent head trauma, ${ }^{30} 31$ contact with certain chemicals such as pesticides, formaldehyde, organic solvents and heavy metals. $^{23}$ 32-37 Another controversial hypothesis, often cited, is that physical activity, whether occupational or leisure related, is a risk factor for SALS ${ }^{38-43}$ This theory is sustained by the higher risk of ALS in professional soccer players. ${ }^{31} 44-49$

On the Pacific island of Guam, ALS-Parkinsonism dementia complex (ALS-PDC), which presents similarly to ALS, occurred at 50 to 100 times the incidence seen worldwide in the 1950s. ${ }^{50} 51$ An epidemiological study established that consumption of a Chamorro diet was the only variable significantly associated with disease incidence. $^{52}$ In 1967, Vega and Bell ${ }^{53}$ discovered a neurotoxin, $\beta$-N-methylamino-L-alanine (L-BMAA), in the genus Cycas, the seeds of which are used to make flour. Hence, L-BMAA could have been consumed by Chamorro people through multiple dietary sources, including cycad flour as well as meat from flying foxes and other animals that feed on cycad seeds. ${ }^{54-57}$ In the 1990s, L-BMAA was proposed as a cause of ALS-PDC. ${ }^{58}$ This hypothesis is supported by the presence of L-BMAA in brain tissues of patients with ALS-PDC and ALS from Guam and Canada, as well as by its absence in controls. ${ }^{55} 5659$ In vitro and in vivo experiments also suggest that L-BMAA plays a role in neuropathological processes implicated in ALS. Indeed, the treatment of dissociated mixed spinal cord cultures with a concentration of L-BMAA around $30 \mu \mathrm{M}$ caused selective motor neurone loss. ${ }^{60}$ Moreover, monkeys fed with large doses of the toxic acid from cycads developed neurological impairments: damaged motor neurones in the spinal cord produced a flaccid paralysis and then damaged neurones in the striatum and cortex, which produced Parkinsonism and behavioural changes. ${ }^{61}{ }^{62}$ In rats, although the intraperitoneal injection of L-BMAA did not provoke any obvious motor dysfunction, ${ }^{63}$ it induced markers of oxidative stress in the liver and cellular changes in favour of apoptosis in motor neurones of the spinal cord. ${ }^{63}{ }^{64}$ In neonatal rats, L-BMAA induced significant systemic changes in energy metabolism and amino acid metabolism (identification of initial metabolite changes for lactate, acetate, D-glucose, creatinine and 3-hydroxybutyrate). ${ }^{65}$ Together, these findings suggest that acute toxicity of L-BMAA induces developmental alterations that result in long-term effects on brain function. L-BMAA is also found to be associated with proteins in cyanobacteria ${ }^{55} 66 \quad 67$ and in brain tissue of patients with ALS. $^{555968}$ It has recently been proposed that L-BMAA may be misincorporated into proteins and thus may lead to protein aggregation, a hallmark of neurodegenerative diseases, ${ }^{69} 70$ inducing a chronic exposure to low levels of L-BMAA. ${ }^{69}$

First of all, L-BMAA was found to be produced by a wide range of cyanobacteria ${ }^{55} 56666771-73$; recently, it was shown that diatoms, the most common group of algae, could also produce it. ${ }^{74}$ However, the level of free or bound L-BMAA detected in cyanobacteria is controversial and the high concentrations reported in the first studies were challenged by several recent studies. L-BMAA could be transferred from cyanobacteria or diatoms via zooplankton to organisms at higher trophic levels. ${ }^{75}$ Cox and collaborators have interestingly highlighted the biomagnification (increasing accumulation of bioactive, often deleterious, molecules through successively higher trophic levels of a food chain) of L-BMAA in trophic chain, ${ }^{54} 567677$ explaining the large amounts detected in flying foxes from Guam. ${ }^{54-57}$

Owing to eutrophication and, to a lesser extent, climate changes, ${ }^{78}$ cyanobacterial blooms seem to be increasing in freshwater ecosystems worldwide. France is not exempt from this phenomenon as different genera of cyanobacteria are found on its territory. ${ }^{80-83}$ Therefore, exposure of French patients with ALS to cyanobacteria, and thereby to cyanotoxins as L-BMAA, ${ }^{84}$ is a reasonable hypothesis that could potentially explain some ALS cases.

The French BMAALS program ${ }^{85}$ takes advantage of (1) the existing federation of BMAALS consortium members in the French network on ALS clusters detection and investigation, supported by INSERM (Institut National de la Santé et de la Recherche Médicale) and (2) of geoepidemiology to investigate patients' environment (dwelling, occupational and leisure) in order to assess spatial association (not cause-and-effect) between ALS cases and a putative cyanobacterial exposure in combination with patients' history about prior exposures. Furthermore, a case-control study will be performed to investigate the potential routes of contamination by L-BMAA, which are: (1) ingestion of contaminated drinking water or dermal contact in recreational water ${ }^{75} 86-89$; (2) consumption of aquatic or terrestrial food previously exposed to toxins $55 \quad 75 \quad 84 \quad 90-93$; (3) cyanobacterial dietary supplements which are rich in protein content ${ }^{739495}$ and (4) inhalation or aerosolisation. ${ }^{96-99}$ To assess the exposure of patients to L-BMAA, 
a reliable quantification method has been developed and validated. To the best of our knowledge, this is the first ambitious project to investigate the link between L-BMAA and ALS in France.

\section{METHODS AND ANALYSIS BMAALS programme}

The main objective of the BMAALS programme is to improve our knowledge on the putative links between the occurrence of ALS and the neurotoxin L-BMAA by studying the defined geographical regions in France. To reach our aim, the BMAALS group (a multidisciplinary consortium of epidemiological, neurological, chemical, microbiological and environmental experts) was created in 2011. The protocol was reviewed and approved by the ethical committee of the CPP SOOM IV (Comite de Protection des Personnes Sud-Ouest \& Outre-Mer IV) on 10 February 2011.

The protocol is organised in six steps:

1. An exhaustive ascertainment of all incident ALS cases was performed for the period under study and in the areas under surveillance.

2. Based on this case ascertainment, geostatistical analyses will allow identification of clusters, characterised as abnormal aggregates of affected people, according to incidence calculations.

3. A population-based case-control study will be performed taking into account notable clusters previously identified.

4. Mapping of factors conducive to algae blooms will help assess indirect exposure of patients to cyanobacteria and, by extension, to cyanotoxins.

5. Collection of tap water, fruits and vegetables from the gardens (among those cultivating), as well as irrigation water will assess direct exposure of patients to L-BMAA. These results will be compared with findings from control environments.

6. Postmortem analysis of voluntary SALS-donors' and control-donors' brains will permit evaluation of bioaccumulation of L-BMAA in French patients.

\section{Case ascertainment}

\section{Spatial and temporal dimensions}

The programme covers the period from 1 January 2003 to 31 December 2011 and involves 10 counties from three French areas (equivalent to districts or subdistricts in some other countries), namely Limousin with 3 departments out of 3, Languedoc-Roussillon with 2 departments out of 5 and Rhône-Alpes with 5 departments out of 8 (figure 1). Owing to the long study period (9 years) and the extended area (5 230 000inhabitants), this represents more than 47 million individuals PYFU (table 1).

\section{Case ascertainment methodology}

The methodology applied here is consistent with that used for the the French register of ALS in Limousin
(FRALim register). ${ }^{100}$ Case ascertainment began with the creation of the consortium in 2011 and is now complete.

Patients were required to meet the following inclusion criteria: (1) living in the area under study at the time of diagnosis; (2) diagnosed with ALS that is definite, probable or probably laboratory supported (excluding clinically possible cases) according to El Escorial revised criteria (EERC) ${ }^{101} 102$ and (3) they were identified by at least one source of ascertainment (out of three). After obtaining authorisations from CCTIRS (Comité Consultatif sur le Traitement de l'Information en matière de Recherche dans le domaine de la Santé) and CNIL (Commission Nationale de l'Informatique et des Libertés), nominative data are obtained from the French national coordination of ALS referral centres, public and private hospitals in the areas of interest, and health insurance data related to long-duration diseases.

\section{First source: French national coordination of ALS referral centres}

Since 2003, all French ALS referral centres share a common database (Ictrals and then CleanWeb) that collects information about patients. The CleanWeb database was authorised by the CNIL on 27 May 2011. Two kinds of information are gathered: (1) sociodemographic data (first and last name, age, birthday, current address and date of death if applicable) and (2) clinical data such as EERC, form of onset (spinal or bulbar), symptoms, ALS functional rating scale-revised, manual muscular testing and ${ }^{103}$ diagnosis delay. ${ }^{104}$

\section{Second source: public and private hospitals}

Hospital medico-administrative data from inpatients with a G12.2 code, corresponding to motor neurone disease according to the international classification of disease 10th version in any of their medical records (principal, related, significantly associated or documentary associated diagnosis), were collected. New cases so determined were further analysed by a neurologist to confirm the ALS diagnosis and EERC.

\section{Third source: health insurance bodies}

Health insurance bodies were asked to help by identifying patients declaring a long-duration disorder coded ALD ${ }^{\circ} 9$, specific to ALS according to the French Haute Autorité de Santé. Four important French institutions agreed to participate: the principal one was the "régime général", which concerns $75 \%$ of the French population, and the three others were specific to subgroups of people: (1) the "régime agricole, mutuelle sociale agricole" for those in the agricultural domain, (2) the "régime social des indépendants", which deals with artisans, traders, industrialists and private professionals and (3) the "caisse nationale militaire de sécurité sociale" for military employees. For patients recruited from these sources, EERC was also reviewed in a centralised way. 


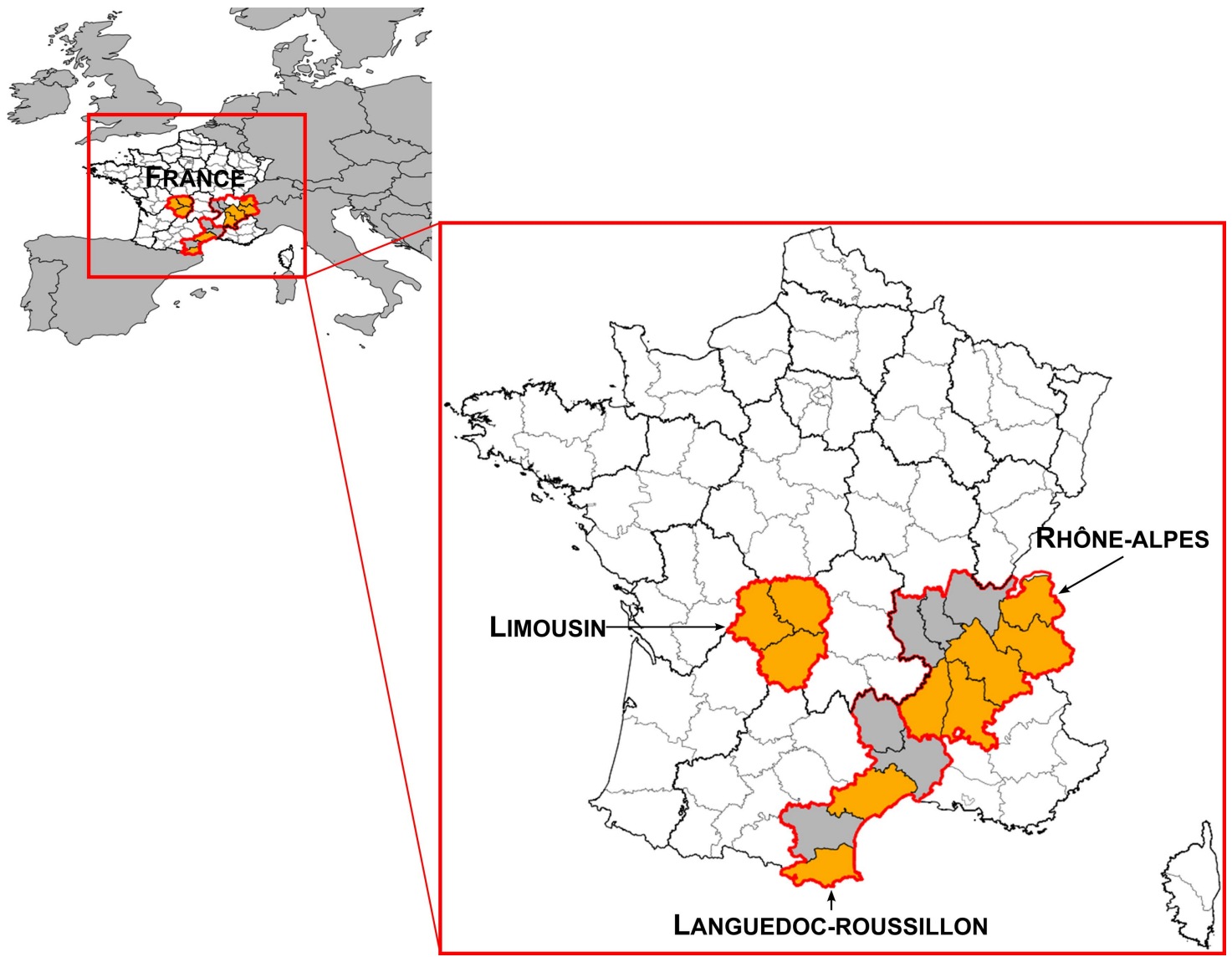

Figure 1 Areas under study in the BMAALS programme. BMAALS is a French project with collaboration between three regions: Limousin, Languedoc-Roussillon (2 departments out of 5) and Rhône-Alpes (5 departments out of 8 ).

In order to verify the completeness of the recruitment of incident ALS cases in the period of time and area of interest, we will use a capture-recapture method (figure 2). ${ }^{105}{ }^{106}$ Matching multiple sources of

\begin{tabular}{|c|c|c|}
\hline & $\begin{array}{l}\text { Mean population } \\
(2003-2011)\end{array}$ & PYFU \\
\hline \multicolumn{3}{|l|}{ Limousin } \\
\hline Corrèze & 239630 & 2156666 \\
\hline Creuse & 123179 & 1108607 \\
\hline Haute-Vienne & 368404 & 3315632 \\
\hline \multicolumn{3}{|l|}{ Languedoc-Roussillon } \\
\hline Hérault & 1007451 & 9067055 \\
\hline Pyrénées-Orientales & 433243 & 3899187 \\
\hline \multicolumn{3}{|l|}{ Rhône-Alpes } \\
\hline Ardèche & 307119 & 2764067 \\
\hline Drôme & 471348 & 4242128 \\
\hline Isère & 1175146 & 10576314 \\
\hline Savoie & 404247 & 3638219 \\
\hline Haute-Savoie & 707077 & 6363693 \\
\hline Total & 5236844 & 47131568 \\
\hline
\end{tabular}

Data from INSEE, French Institut National de la Statistique et des Etudes Economiques.

PYFU, person-years of follow-up. information from a unique population allows for estimation of the number of cases unidentified by any source, the total number of cases and the exhaustiveness of each source.

This methodology of case ascertainment uses the same three sources that have been previously applied in the FRALim register ${ }^{100}$ (first register of ALS in France, located in Limousin, for the period 2000-2011). We estimated, thanks to the capture-recapture analysis, an exhaustiveness of the register of $98.4 \%$ (95\% CI 95.6\% to $99.4 \%$ ), yielding a low number of false-negative cases $^{100}$ (ie, missed cases). Data from private neurologists were not obtained because most lacked computerised records and a retrospective chart review was not feasible.

\section{Geoepidemiology}

Geographic information systems (GIS) will be used to structure and analyse geographic information collected or produced in the context of the programme. In France, the legal geodesic network reference, established by the French Institut National Géographique et Forestière (IGN), is RGF93 (the French geodesic network set up in 1993). Thus, all cartography carried out by the BMAALS consortium will be projected in RGF93. 
Figure 2 Multiple sources of case ascertainment. For the application of a capture-recapture method, three sources were solicited: (1) the French national coordination of amyotrophic lateral sclerosis (ALS) referral centres, (2) public and private hospitals and (3) health insurance structures.

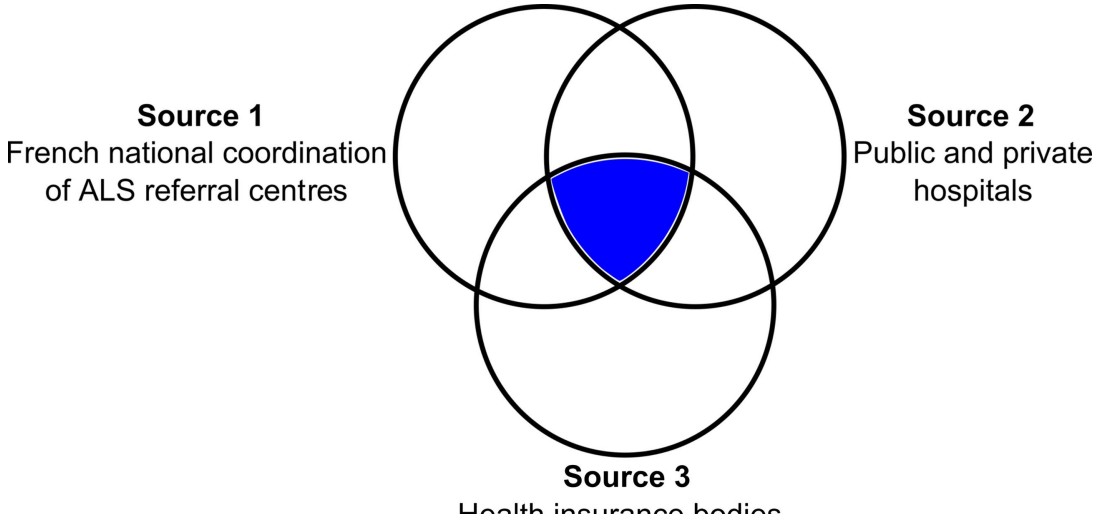

Health insurance bodies
To ensure comprehensive data analysis, we have decided to investigate three levels as described below (figure 3).

\section{First level, smallest geographic unit: ALS incidence}

According to Knox, ${ }^{107}$ a cluster in epidemiology is defined as "a geographically bounded group of occurrences of sufficient size and concentration to be unlikely to have occurred by chance". Recently, Elliott and Wartenberg $^{108}$ wrote that "the term disease cluster is poorly defined but implies an excess of cases above some background rate bounded in time and space". Thus, those imprecise definitions do not explain clearly what a cluster is: how many cases do we need for considering having a cluster?

When considering a rare disorder such as ALS, one inherent issue is the small number of events. Therefore, it is necessary to consider a large population obtained by aggregating cases over many years and/or by using a large geographical area. Indeed, individual clusters should not be investigated unless a sufficient number of cases is reached (five or more) and relative risks (RR) in a particular area are higher than 20. ${ }^{109} 110$ However, among five articles published since the year 2000 and dealing with spatial clustering of ALS, only one team found clusters with high RR (table 2). ${ }^{111}$

In the BMAALS programme, overincidence clusters are defined as areas where RR is found as being greater than 1.8, while underincidence zones are those characterised by an RR lesser than 1 .

After case ascertainment, addresses of patients included in the programme will be geocoded. Districts defined as life areas are the chosen grouping units with which to measure expected cases. According to the French Institut National de la Statistique et des Etudes Economiques (INSEE), a life area is the smallest territory unit in which inhabitants have access to common equipment and services.

Expected case values depend on the demographical structure (age and sex) of the exposed population, given their observed incidence in the 10 studied counties (table 1). Then a standardised incidence ratio (SIR)

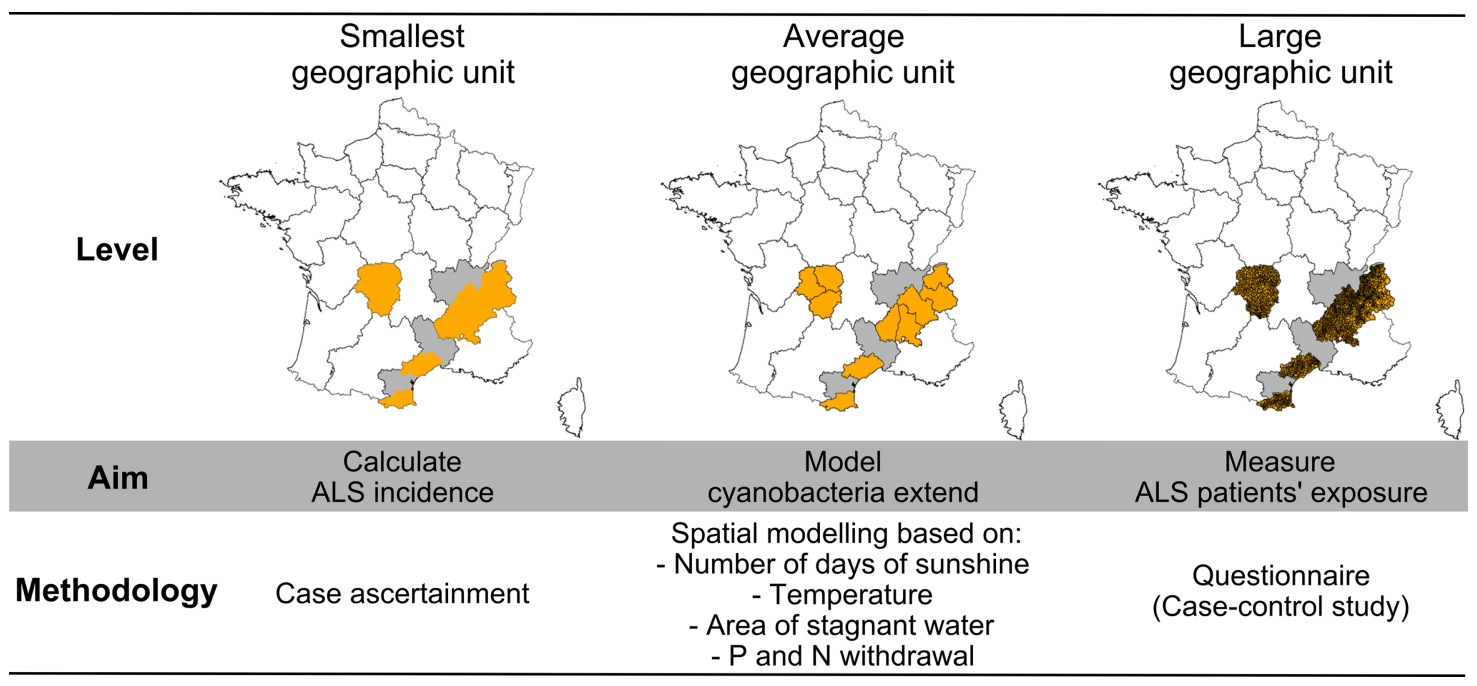

Figure 3 The three levels considered for geostatistical analyses. Aims and methodologies applied are represented for each of the three levels: from the smallest geographic unit for calculating ALS incidence; through the average geographic unit for studying the cyanobacteria extent; to finally the largest geographic unit for assessing exposure of patients with ALS (ALS, amyotrophic lateral sclerosis; $\mathrm{P}$, phosphorus; $\mathrm{N}$, nitrogen). 
Table 2 Spatial clustering of ALS

\begin{tabular}{|c|c|c|c|c|c|c|c|c|c|c|}
\hline Authors & Year & Location & Period & Duration & $\mathbf{O i}$ & $\mathbf{E i}$ & RR min & Oi & $\mathbf{E i}$ & $\mathbf{R R} \max$ \\
\hline Uccelli et al ${ }^{111}$ & 2007 & Italy & 1980-2001 & 22 & 149 & 91.82 & 1.63 & 41 & 0.65 & 63.03 \\
\hline Turabelidze et $a l^{112}$ & 2008 & $\begin{array}{l}\text { Jefferson county, } \\
\text { Missouri }\end{array}$ & 1998-2002 & 5 & 3 & 0.47 & 6.4 & 3 & 0.47 & 6.4 \\
\hline Doi et $a l^{113}$ & 2010 & Japan & 1995-2004 & 10 & 384 & 276.71 & 1.26 & 181 & 115.70 & 1.56 \\
\hline Boumediene et $a^{26}$ & 2011 & Limousin, France & 1997-2007 & 11 & 9 & 2.30 & 3.91 & 6 & 1.24 & 4.84 \\
\hline Masseret et a/84 & 2013 & Hérault, France & 1994-2009 & 16 & 9 & 4.10 & 2.19 & 4 & 0.71 & 5.63 \\
\hline
\end{tabular}

will be determined by calculating the ratio between the number of observed cases and the number of expected cases. The significance of SIR compared with global incidence will be evaluated using a Poisson distribution (95\% confidence). Geostatistical analyses, based on Kulldorff statistics, will be performed to identify areas of significant overincidence or underincidence as compared with the referral incidence value, which is the global incidence in the whole area under study. ${ }^{26}$

This first cartography is useful for tracking interesting sites for patients' interview.

\section{Second level, average geographic unit: cyanobacterial bloom investigation}

Numerous physical parameters favour the extensive propagation of cyanobacteria, such as warmer temperatures, particular rainfall patterns, windiness and consequently the intensity of thermal stratification of the water column. ${ }^{114-116}$ Moreover, bloom-forming cyanobacteria have been shown to be favoured by high alkalinity and associated high $\mathrm{pH}^{117}$ The increasing magnitude and frequency of cyanobacterial blooms is also related to the nutrient enrichment (phosphorus, $\mathrm{P}$, and nitrogen, $\mathrm{N}$ ) of freshwater ${ }^{118-122}$ and input of micronutrients such as iron and molybdenum. ${ }^{123} 124$ A recent model has identified higher risk lake environments where a more targeted monitoring of cyanobacterial biovolumes should be focused: water colour $10-20 \mathrm{Pt} / \mathrm{L}$, alkalinity $>1 \mathrm{mEq} / \mathrm{L}$, retention time $>30$ days and total $\mathrm{P}>20 \mu \mathrm{g} / \mathrm{L}$. ${ }^{125}$

All these parameters should be considered when carrying out descriptive cartography and tracing the history of cyanobacterial blooms. To do that, we will make use of various free-to-access databases such as: Basias (Bureau de Recherches Géologiques et Minières, BRGM), which compiles lists of plants located on French territory that are susceptible to the release of $\mathrm{P}$, $\mathrm{N}$ and nutrients in water; data furnished by water agencies concerning measurements of industrial pollutant emissions and wastewater treatment plants; ADES portal (Accès aux Données sur les Eaux Souterraines), which gives access to water channelling points and water consumption quality control. Moreover, a convention with Météo France, the French organisation for meteorology, has been signed to retroactively view climate conditions over the period 2003-2011 and before. All these data will be integrated into our GIS to create a complete database, and also to identify sites of interest for sampling.

Geographic statistics will then be performed in order to classify each administrative unit (eg, municipality) according to four parameters: (1) the number of days of sunshine, (2) temperature, (3) the area of stagnant water (included dams and ponds) and (4) data on $\mathrm{P}$ and $\mathrm{N}$ withdrawal. For the last one, anthropogenic factors will also be considered as industrial and agricultural activities can impact on $\mathrm{N}$ and $\mathrm{P}$ release (use of organophosphorus compounds, for example). This multicriteria approach will yield an index of proliferation of cyanobacterial blooms. The same will be carried out with watersheds as there is an aggravating effect from upstream to downstream of $\mathrm{P}$ and $\mathrm{N}$ inputs. Finally, a coefficient correlation will be measured between SIR and the calculated index.

This database will also gather information about all plants on French territory, the high-voltage electricity network and stretches of water (ponds, rivers, etc). Hence, it will give a general overview of patients' and controls' industrial and dwelling environments. Geographic statistics based on classification of municipalities as previously described will be used to highlight interesting particularities.

Further analysis of cyanobacterial blooms will involve using a fluorimetric probe to detect the emission and excitation wavelength of phycocyanin, a pigment almost exclusively specific to cyanobacteria. ${ }^{126}$ Water sampling will permit the identification of cyanobacterial species. Gathering information about conditions favourable for cyanobacterial blooms will allow us to model their expansion notably in terms of meteorology and nutrient inputs. Through the use of previously collected data, we will be able to ascertain if there were cyanobacteria prior to patients' diagnosis and the species present, and therefore if there was a risk of L-BMAA presence in water.

\section{Third level: large geographic unit: questionnaire for a case-control study}

This part aims to highlight differences in life habits between patients SALS and controls. Criteria for selecting patients with ALS are as follows: (1) familial history cases are excluded; (2) last known address must be in an overincidence or underincidence area and (3) if possible, vicinity with other affected people, which may 
suggest a close source of an environmental risk factor leading to ALS. Controls will be matched on age at diagnosis, sex and city and should not present any neurological pathologies. Chosen patients and controls will be submitted to a semistructured interview, for example, systematic questions with the possibility of free interview to look in more depth at particular issues raised. The questionnaire has been developed by the consortium specifically for the BMAALS programme.

On the basis of the initial results of clustering, ${ }^{26} \mathrm{a}$ number of clusters to investigate was selected a priori: 3 overincidence areas in Limousin, 2 in LanguedocRoussillon and 4 in Rhône-Alpes; with an expected number of 4 patients in each cluster (and 4 controls), this will represent a total of about 72 interviews. The same number of interviews for patients and controls will be performed in underincidence areas. Owing to the short survival time of the disease, the number of living patients diagnosed between 2003 and 2011 is low. Thus, when necessary, relatives will be questioned.

Cyanobacterial and L-BMAA hypotheses are tested via questions about: (1) drinking water; (2) bathing habits; (3) food consumption including dietary supplements (to be specified if applicable), the type of supplement is informed and (4) irrigation water, if any. The aim of the questionnaire is to obtain a comprehensive description of patients' habits in all aspects of their lives. Hence, it will be made clear that questions are not just about the time immediately preceding the diagnosis.

To assess exposure to cyanotoxins indirectly, an ad hoc questionnaire is a useful supplement to direct collection of environmental samples. ${ }^{127}$ Hence, samples will be taken in case and control environments to test for the presence of cyanobacteria in water (the same probe as described above) and for further chemical analysis (in water and food).

To ensure that L-BMAA is most likely to be implicated, the questionnaire also covers items already described in the literature such as dwelling location (urban/rural), occupation, presence of certain industries in the dwelling environment, toxic exposure during employment or hobbies, participation in sport, physical trauma, alcohol and tobacco consumption. ${ }^{23} 26323348{ }^{128-131}$ As there is probably a long latency period between exposure and appearance of ALS ${ }^{132} 133$ and given that L-BMAA exists in a protein-associated form which could act as an endogenous neurotoxic reservoir over time, ${ }^{55}$ an in-depth study will involve gathering details of dwelling since birth (in order to collect their precise residential history), and for other items from age 13. Indeed, the French population is regularly subject to migratory flows (figure 4) and it has to be considered in our study.

All information gathered will be used to map the spaces where patients live for further analysis to identify common places, and also to further analyse the cyanobacterial history of these areas.

\section{Chemical and microbiological approaches}

An analytical procedure has been developed and validated in our programme for the determination of underivatised L-BMAA at trace levels in complex environmental matrices (cyanobacteria, biofilm, food, human brain tissue, plasma or urine) using solid-phase extraction based on mixed mode sorbent to concentrate and clean up real complex samples. ${ }^{134}$ The methodology of quantification relies on liquid chromatography (LC) coupled to tandem mass spectrometry (LC-MS/MS). The proportion of free and then bound L-BMAA in cyanobacterial proteins will be measured.

In parallel, a microbiological study will be undertaken involving the culture of axenic cyanobacteria strains from various origins and ecosystems (terrestrial, aquatic, fresh water, sea water or brackish water), as was conducted in seminal work by Cox et al. ${ }^{67}$ By using the analytical method described above, free L-BMAA will be quantified in environmental and biological samples. Moreover, kinetic experiments will assess whether L-BMAA production is constitutive or if variations of concentration are observed over time. Finally, isotopic incorporation experiments using various labelled amino acid should help identify the putative precursors of L-BMAA.

\section{Implications of results for searching theoretical models}

A synthesis of the results of the steps described above aims to develop a cyanobacterial proliferation model based on environmental and microbiological data, on the one hand, and to detail population exposure to L-BMAA relying on the detection of the presence of L-BMAA in patients' environment, on the other. First,
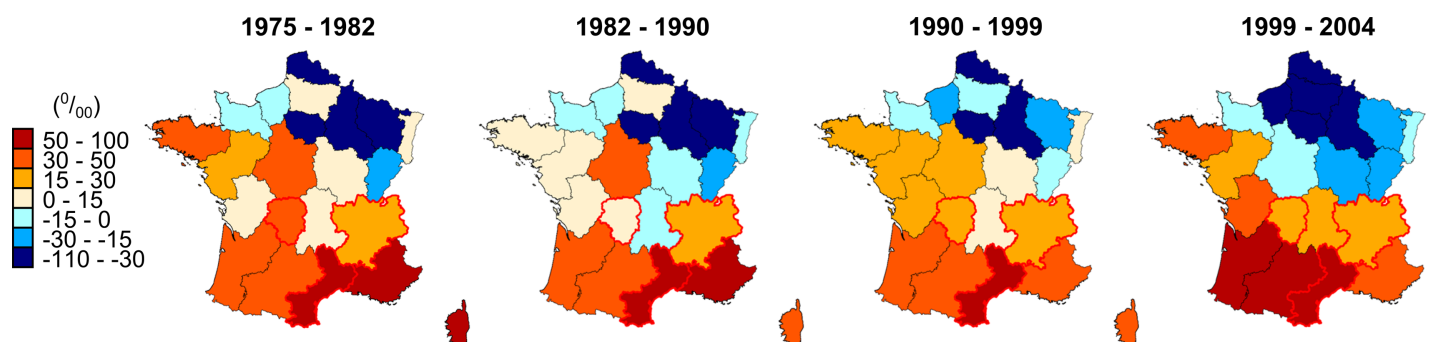

Figure 4 Residential migration rate of the French population. These maps reflect the intraregional mobility of the French people from 1975 to 2004 . The residential migration rate is expressed per 1000 persons. (Data from INSEE, Institut National de la Statistique et des Etudes Economiques). 
environmental data will serve to identify climatic parameters (sunshine, temperature, rainfall and wind patterns) favourable for cyanobacterial blooms; microbiological analyses will allow one to determine propitious conditions leading to L-BMAA production by cyanobacteria. Population exposure will be studied by (1) comparing industrial occupation between overincidence and underincidence areas; (2) assessing the risk of exposure through public facilities and infrastructure and (3) examining differences in habits between cases and controls.

\section{DISCUSSION}

The present project aims to better describe the link between ALS, the neurotoxin L-BMAA and cyanobacteria through the use of case ascertainment, spatial clustering, questionnaires and chemical analyses.

Food frequency questionnaires prove to be reliable for long-term recall, from 8 to 24 years ${ }^{135-139}$ : hence, they appear to be a good alternative to food diary recall for diseases with a potential long-term incubation. However, the BMAALS project concerns three French regions which are irregular in terms of population density: Rhône-Alpes has about 141 inhabitants $/ \mathrm{km}^{2}$ (in 2009), Languedoc-Roussillon about 95 inhabitants $/ \mathrm{km}^{2}$ (in 2007) and finally, the least populated of the three is Limousin with 43 inhabitants $/ \mathrm{km}^{2}$ (in 2010; INSEE figures). This heterogeneity, combined with the long period studied (2003-2011) and the rapid death of patients, led to a major difficulty in finding living patients for questionnaires, in particular in Limousin. So patients' relatives are interviewed, which can induce a bias in responses. ${ }^{140}$ To avoid any misinterpretation of the question concerning dietary habits, it is clearly clarified that it concerns habits before diagnosis and first symptoms. Moreover, we have also developed a selfadministered questionnaire given to all patients with ALS (not only those included in our programme) and will compare answers between patients since 2012 and those from 2003 to 2011 (ancillary study).

Likewise, owing to the fact that ALS is a rare disorder, areas of significant underincidence are characterised by the absence or almost absence of patients. With regard to multiple source case ascertainment, we recognise that some patients might be missed because of the difficulty in diagnosing ALS in elderly people due to the confusion between ALS symptoms and decline due to ageing. Another important issue is the low participation rate for postmortem analysis: at the time of the writing, few patients have given their consent to a postmortem swab, thereby perhaps reducing the impact of our study.

The hypothesis of L-BMAA exposure as an environmental risk factor in ALS pathology is controversial, notably because of the contradictory results. Intoxication assays with the toxin yielded uneven results. ${ }^{141}$ With regard to experimental designs, it appears that the neurotoxic effect of L-BMAA: (1) depends on the mode of administration, (2) is species dependent and (3) genetic predisposition may also be at play. ${ }^{142}$ For example, two teams failed to develop a mouse model by daily oral administration of L-BMAA $(0.001$ and $0.5 \mathrm{~g} / \mathrm{kg}),{ }^{143}{ }^{144}$ whereas Spencer and collaborators have developed a simian model by the daily oral administration of L-BMAA with doses ranging from 0.1 to $0.3 \mathrm{~g} / \mathrm{kg} .{ }^{61}{ }^{62}$ Furthermore, other murine models based on intraperitoneal and intracerebroventricular injections of L-BMAA in mice and rats lead to effective behavioural changes. ${ }^{63}$ 145-151 Other work strengthens the L-BMAA hypothesis by highlighting the implication of the toxin in other degenerative diseases such as Alzheimer's disease (AD), Parkinson's disease and pigmentary retinopathy. ${ }^{55} \quad 56 \quad 59 \quad 68 \quad 152 \quad 153$ Although the mechanism of action is not yet completely understood, it seems that L-BMAA neurotoxicity involves: (1) direct action on N-methyl-D-aspartate receptors; (2) activation of glutamate receptor 5, (3) induction of oxidative stress ${ }^{154} 155$ and (4) association to protein due to mischarging of transfer RNA. ${ }^{69}$ Moreover, a recent study has shown that L-BMAA leads to an increase in the insoluble TAR DNA-binding protein 43 (TDP-43), ${ }^{156}$ the aggregation of this protein being an important hallmark in neurodegenerative diseases. ${ }^{157}$ To further support our seminal hypothesis, it is interesting to note that microcystin-leucine-arginine, a cyanobacterial toxin, has been shown to be involved in AD. ${ }^{158} 159$

Another debatable point concerns the quantification of L-BMAA, given that the concentrations measured vary depending on the analytical method used (figure 5). The crucial issue is to develop a method that distinguishes L-BMAA from its isomers and amino acids to achieve a selective titration method. Currently, the most widely used L-BMAA quantification method is LC-MS/ MS. ${ }^{68} 7275$ 90-92 160 A prederivatisation step, prior to LC separation, has also frequently been described using 6aminoquinolyl-N-hydrosuccinimidyl carbamate (6-AQC), a fluorescent derivative agent. In that case, the analyte was either detected by fluorescence or by tandem MS. However, a major drawback of this prederivatisation is the likelihood of false-positive results. ${ }^{161}$ A comparison of five standard methods, namely high-pressure LC with fluorescence detection (HPLC-FD), ultra HPLC (UHPLC)-MS/MS, UHPLC-MS/MS with AQC or propyl chloroformate derivatisation and UHPLC with ultraviolet detection shows that they all clearly distinguish L-BMAA from other amino acids. ${ }^{162}$ One team succeeded in detecting L-BMAA in brains from patients with ALS-PDC or AD by using HPLC-FD and samples derivatised with 6-AQC, 55565968 while other teams failed to detect any L-BMAA in patients' brains by using HPLC-FD with samples derivatised with 9-fluorenylmethylchloroformate (FMOC) or by gas chromatography (GC). ${ }^{163} 164$ These results suggest that either HPLC-FD with a 6-AQC derivatisation is more sensitive than HPLC-FD with an FMOC derivatisation or 6-AQC derivatisation generates falsepositive results. The GC method has been improved to 


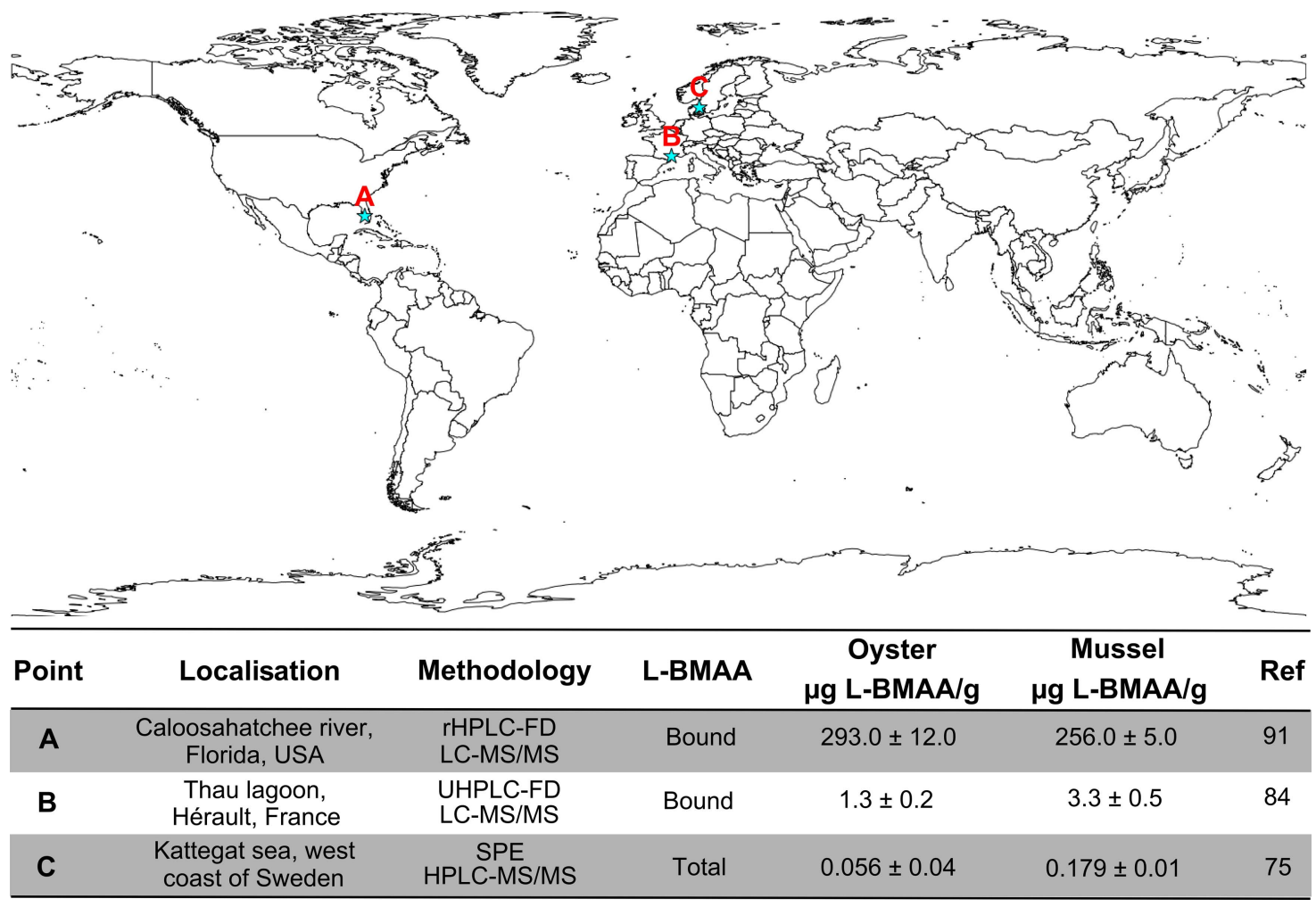

Figure 5 L-BMAA quantification in molluscs throughout the world. A comparison of three quantification methods and teams highlights discrepancies in L-BMAA titration. Does that reveal a difference in selectivity of the method or the existence of a gradient of the neurotoxin? L-BMAA levels are expressed as $\mu \mathrm{g} L-B M A A / g$ dry weight $\pm S E$ (FD, fluorescence detection; L-BMAA, $\beta-N-m e t h y l a m i n o-L-a l a n i n e ; ~ L C$, liquid chromatography; LC-MS/MS: LC coupled to tandem mass spectrometry; HPLC, high-pressure LC; rHPLC: reverse phase HPLC; SPE, solid phase extraction; UHPLC, ultra HPLC).

enhance recovery but was still inefficient in detecting L-BMAA in brains of mice fed with it. ${ }^{165}$ This was later made possible, but it is still not efficient in human tissues. ${ }^{166}$ This illustrates the importance of continuing to improve analytical methods.

It has been shown that HPLC-FD overestimates L-BMAA concentration, due to low selectivity, with estimates in the high $\mu \mathrm{g} / \mathrm{g}$ range rather than in the more realistic $\mathrm{ng} / \mathrm{g}$ to low $\mu \mathrm{g} / \mathrm{g}$ range. The $\mathrm{LC}-\mathrm{MS} / \mathrm{MS}$ method is more selective and gives more reliable results. ${ }^{160}$ One major argument in favour of using underivatised methods is that the universal 6-AQC derivatisation of primary and secondary amines could lead to misidentification of L-BMAA in complex matrices. ${ }^{161}$ The method we propose here ${ }^{134}$ based on LC/MS-MS, over-rides the derivatisation step, unlike another recent new method developed, ${ }^{167}$ and allows the quantification of L-BMAA at trace levels, but it remains to be adapted for quantification of L-BMAA in all the matrices needed in the programme.

Inability to detect L-BMAA in patients' brains casts doubt on its bioaccumulation. Addressing this issue, we can argue that: (1) L-BMAA crosses the blood-brain barrier (BBB) ${ }^{61} \quad 62 \quad 166 \quad 168$ and (2) there is a scientific consensus on the bioaccumulation of L-BMAA in trophic chains, which has been shown by several teams in seafood. ${ }^{75} 90-92169$ Together, these results suggest that
L-BMAA after having crossed the BBB can be bioaccumulated, as it is concentrated in brains of other organisms. ${ }^{57} 7591$ Furthermore, a brief review of the literature reveals that L-BMAA has been quantified in the brain using MS. ${ }^{55} 565968{ }^{164}$ Glover et al ${ }^{170}$ showed that failure to detect L-BMAA cannot be considered proof of absence of the compound because of its reactivity with metal ions in the sample matrix and the formation of metal adducts during electrospray ionisation MS. However, this problem should be overcome by quantifying the matrix effect by using spiked samples with pure standards. $^{134}$

Nonetheless, finding putative sources of L-BMAA contamination is proving very difficult. To illustrate this point, we can cite Karlsson et $a l^{70}$ who demonstrated L-BMAA clearance: in 7-month-old neonatal rats, there is no detectable free or protein-associated L-BMAA. The authors suggest that observed long-term protein changes and cognitive impairments in adult animals exposed to L-BMAA as neonates ${ }^{171-174}$ are due to mechanisms initiated during development. Hence, the clearance mechanism may lead to the inability to detect L-BMAA in patients' brains, but that does not mean that L-BMAA is innocuous pathologically. Besides, neonatal contamination is conceivable as Andersson et $a l^{175}$ have shown that L-BMAA can be transferred to neonates during lactation via breast milk. This new route of contamination 
conspicuously complicates the identification of an environmental risk factor. Moreover, as ALS is probably a gene-environment disease, attention must also be paid to genetic and epigenetic factors. ${ }^{176-179}$ For example, genetic susceptibility to environmental toxins-heavy metals, solvents/chemicals and pesticides/herbicideshas been reported. ${ }^{180}$

It is of major importance to identify environmental risk factors causing SALS. The protocol presented here aims to study the link between L-BMAA and ALS in France by characterising exposure modalities, either individual or collective, to cyanobacteria and more precisely to the L-BMAA toxin. Thanks to the questionnaire, it also intends to shed light on other assumptions formulated in literature as putative origins for SALS (as occupational exposure and sports practising). Finally, our results could be used to generate a guide of precautions against behavioural risk leading to exposure to L-BMAA.

In conclusion, the results of this project should help to (1) give a clear picture of ALS distribution over 10 French counties; (2) identify clusters where environmental factors may play a greater role than elsewhere; (3) provide information about some environmental specificities of ALS clusters, especially regarding factors related to cyanobacteria presence and proliferation as also BMAA presence and (4) see to what extent the BMAA hypothesis seems to be relevant regarding the explanation of SALS clusters within the large French area considered. Despite limitations mainly due to i) interviews of patients' relatives and ii) the controversy on L-BMAA analysis, this programme is of importance because it is the first to investigate the cyanobacteria hypothesis in France.

\section{Author affiliations}

${ }^{1}$ Tropical Neuroepidemiology, INSERM UMR 1094, Limoges, France

${ }^{2}$ University of Limoges, School of Medicine, Institute of Neuroepidemiology and Tropical Neurology, Centre national de la recherche scientifique FR 3503 GEIST, Limoges, France

${ }^{3}$ Department of Neurology, ALS Center, University Hospital Dupuytren, Limoges, France

${ }^{4}$ Interdisciplinary Laboratory for Tomorrow's Energy Pack (LIED), CNRS UMR 8236, University Paris Diderot-Paris 7, Paris, France

${ }^{5}$ UMR 6553 ECOBIO, Ecosystems-Biodiversity-Evolution, University Rennes I, Rennes, France

${ }^{6}$ Department of Analytical, Bioanalytical Sciences and Miniaturization (LSABM), UMR ESPCI-ParisTech-CNRS $8231 \mathrm{CBI}$, Paris, France

${ }^{7}$ University Sorbonne, University Pierre and Marie Curie (UPMC), Paris, France

${ }^{8}$ Environment and Health Prediction in Populations (EPSP), CNRS-TIMC-IMAG UMR 5525 UJF-Grenoble 1, Grenoble, France

${ }^{9}$ Department of Neurology, University Hospital of Grenoble, Grenoble, France

${ }^{10}$ Biomathematics and Epidemiology, Environment and Health Prediction in

Populations (EPSP), VetAgro Sup, Marcy-l'Etoile, France

${ }^{11}$ Motoneuron Diseases: Neuroinflammation and Therapy, INSERM UMR

1051, Neurosciences Institute, Montpellier, France

${ }^{12}$ Department of Neurology, ALS Center, University Hospital Gui de Chauliac, Montpellier, France

${ }^{13}$ UMR 5119 ECOSYM, Ecology of Coastal Marine Systems, UM2-CNRS-IRDIfremer-UM1, University Montpellier II, Montpellier, France

${ }^{14}$ Environment Resources Laboratory/Languedoc-Roussillon, Ifremer, Sète, France
Acknowledgements The authors thank all institutes which collaborated with case ascertainment. The authors gratefully acknowledge William Francis for careful editing of the manuscript.

Contributors PC, BM, P-MP, MD-C, FB, EL, VB, DJB, WC, VP and AM were involved in the study conception and design. PC, BM, MN, EL, VB, GB, WC, NP and RJ-M have participated in case ascertainment. $A D$ is responsible for questionnaires. $\mathrm{AM}$ and $\mathrm{OP}$ were involved in the cyanobacteria study. VP, AC and SEA are responsible for chemical analyses. FB and J-PL are geoepidemiologists. LB, ML, EM and EA are environmentalists. FP, JB and VR are anatomopathologists. $A D$ wrote the manuscript, which was finally approved by BM, PC, FB and P-MP. All authors read and approved the final manuscript.

Funding This work is supported by the French National Research Agency (ANR) grant number programme ANR-11-CESA-0014 (Project "BMAALS")

Competing interests None.

Patient consent Obtained.

Ethics approval Comité de Protection des Personnes Sud-Ouest \& Outre-Mer IV

Provenance and peer review Not commissioned; externally peer reviewed.

Open Access This is an Open Access article distributed in accordance with the Creative Commons Attribution Non Commercial (CC BY-NC 4.0) license, which permits others to distribute, remix, adapt, build upon this work noncommercially, and license their derivative works on different terms, provided the original work is properly cited and the use is non-commercial. See: http:// creativecommons.org/licenses/by-nc/4.0/

\section{REFERENCES}

1. Logroscino G, Traynor BJ, Hardiman O, et al. Incidence of amyotrophic lateral sclerosis in Europe. J Neurol Neurosurg Psychiatry 2010;81:385-90.

2. Rosen DR, Siddique T, Patterson D, et al. Mutations in Cu/Zn superoxide dismutase gene are associated with familial amyotrophic lateral sclerosis. Nature 1993;362:59-62.

3. Blasco $H$, Bernard-Marissal N, Vourc'h $P$, et al. A rare motor neuron deleterious missense mutation in the DPYSL3 (CRMP4) gene is associated with ALS. Hum Mutat 2013;34:953-60.

4. Chesi A, Staahl BT, Jovicic A, et al. Exome sequencing to identify de novo mutations in sporadic ALS trios. Nat Neurosci 2013;16:851-5

5. Hermosura MC, Nayakanti $\mathrm{H}$, Dorovkov MV et al. A TRPM7 variant shows altered sensitivity to magnesium that may contribute to the pathogenesis of two Guamanian neurodegenerative disorders. Proc Natl Acad Sci USA 2005;102:11510-15.

6. Majoor-Krakauer D, Willems PJ, Hofman A. Genetic epidemiology of amyotrophic lateral sclerosis. Clin Genet 2003;63:83-101.

7. Deng HX, Chen W, Hong ST, et al. Mutations in UBQLN2 cause dominant $X$-linked juvenile and adult-onset $A L S$ and ALS/dementia. Nature 2011;477:211-15.

8. Al-Chalabi A, Jones A, Troakes $\mathrm{C}$, et al. The genetics and neuropathology of amyotrophic lateral sclerosis. Acta Neuropatho 2012;124:339-52.

9. Niemann $\mathrm{S}$, Joos $\mathrm{H}$, Meyer T, et al. Familial ALS in Germany: origin of the R115G SOD1 mutation by a founder effect. $J$ Neurol Neurosurg Psychiatry 2004;75:1186-8.

10. Battistini S, Giannini F, Greco G, et al. SOD1 mutations in amyotrophic lateral sclerosis. Results from a multicenter Italian study. J Neurol 2005;252:782-8.

11. DeJesus-Hernandez M, Mackenzie IR, Boeve BF, et al. Expanded GGGGCC hexanucleotide repeat in noncoding region of C9ORF72 causes chromosome 9p-linked FTD and ALS. Neuron 2011;72:245-56

12. Smith BN, Newhouse S, Shatunov A et al. The C9ORF72 expansion mutation is a common cause of ALS+/-FTD in Europe and has a single founder. Eur J Hum Genet 2013;21:102-8.

13. Chio A, Borghero G, Restagno G, et al. Clinical characteristics of patients with familial amyotrophic lateral sclerosis carrying the pathogenic GGGGCC hexanucleotide repeat expansion of C9ORF72. Brain 2012;135(Pt 3):784-93 
14. Vance C, Rogelj B, Hortobagyi T, et al. Mutations in FUS, an RNA processing protein, cause familial amyotrophic lateral sclerosis type 6. Science 2009;323:1208-11.

15. Kwiatkowski TJ Jr., Bosco DA, Leclerc AL, et al. Mutations in the FUS/TLS gene on chromosome 16 cause familial amyotrophic lateral sclerosis. Science 2009;323:1205-8.

16. Renton AE, Majounie E, Waite A, et al. A hexanucleotide repeat expansion in C9ORF72 is the cause of chromosome 9p21-linked ALS-FTD. Neuron 2011;72:257-68.

17. Sabatelli M, Conte A, Zollino M. Clinical and genetic heterogeneity of amyotrophic lateral sclerosis. Clin Genet 2013;83:408-16.

18. de Jong SW, Huisman MH, Sutedja NA, et al. Smoking, alcohol consumption, and the risk of amyotrophic lateral sclerosis: a population-based study. Am J Epidemiol 2012;176:233-9.

19. Wang H, O'Reilly EJ, Weisskopf MG, et al. Smoking and risk of amyotrophic lateral sclerosis: a pooled analysis of 5 prospective cohorts. Arch Neurol 2011;68:207-13.

20. Alonso A, Logroscino G, Hernan MA. Smoking and the risk of amyotrophic lateral sclerosis: a systematic review and meta-analysis. J Neurol Neurosurg Psychiatry 2010;81:1249-52.

21. Alonso A, Logroscino G, Jick SS, et al. Association of smoking with amyotrophic lateral sclerosis risk and survival in men and women: a prospective study. BMC Neurol 2010;10:6

22. Gallo V, Bueno-De-Mesquita HB, Vermeulen R, et al. Smoking and risk for amyotrophic lateral sclerosis: analysis of the EPIC cohort. Ann Neurol 2009;65:378-85.

23. Das K, Nag C, Ghosh M. Familial, environmental, and occupational risk factors in development of amyotrophic lateral sclerosis. $N \mathrm{Am} \mathrm{J}$ Med Sci 2012;4:350-5.

24. Beghi E, Pupillo E, Messina $P$, et al. Coffee and amyotrophic latera sclerosis: a possible preventive role. Am J Epidemiol 2011;174:1002-8

25. Nelson LM, McGuire V, Longstreth WT Jr., et al. Population-based case-control study of amyotrophic lateral sclerosis in western Washington State. I. Cigarette smoking and alcohol consumption. Am J Epidemiol 2000;151:156-63.

26. Boumediene F, Druet-Cabanac M, Marin B, et al. Contribution of geolocalisation to neuroepidemiological studies: incidence of ALS and environmental factors in Limousin, France. J Neurol Sci 2011;309:115-22.

27. Hakansson N, Gustavsson P, Johansen C, et al. Neurodegenerative diseases in welders and other workers exposed to high levels of magnetic fields. Epidemiology 2003;14:420-6; discussion 27-8.

28. Li CY, Sung FC. Association between occupational exposure to power frequency electromagnetic fields and amyotrophic lateral sclerosis: a review. Am J Ind Med 2003;43:212-20.

29. Johansen C. Electromagnetic fields and health effectsepidemiologic studies of cancer, diseases of the central nervous system and arrhythmia-related heart disease. Scand J Work Environ Health 2004;30(Suppl 1):1-30.

30. Turner MR, Abisgold J, Yeates DG, et al. Head and other physical trauma requiring hospitalisation is not a significant risk factor in the development of ALS. J Neurol Sci 2010;288:45-8.

31. Lehman EJ, Hein MJ, Baron SL, et al. Neurodegenerative causes of death among retired National Football League players. Neurology 2012;79:1970-4.

32. Johnson FO, Atchison WD. The role of environmental mercury, lead and pesticide exposure in development of amyotrophic lateral sclerosis. Neurotoxicology 2009;30:761-5

33. Kamel F, Umbach DM, Bedlack RS, et al. Pesticide exposure and amyotrophic lateral sclerosis. Neurotoxicology 2012;33:457-62.

34. Vinceti M, Bottecchi I, Fan A, et al. Are environmental exposures to selenium, heavy metals, and pesticides risk factors for amyotrophic lateral sclerosis? Rev Environ Health 2012;27:19-41.

35. Fang F, Kwee LC, Allen KD, et al. Association between blood lead and the risk of amyotrophic lateral sclerosis. Am J Epidemiol 2010;171:1126-33.

36. Pinkerton LE, Hein MJ, Meyers A, et al. Assessment of ALS mortality in a cohort of formaldehyde-exposed garment workers. Amyotroph Lateral Scler Frontotemporal Degener 2013;14:353-5.

37. Weisskopf MG, Morozova N, O'Reilly EJ, et al. Prospective study of chemical exposures and amyotrophic lateral sclerosis. J Neurol Neurosurg Psychiatry 2009;80:558-61.

38. Harwood CA, McDermott CJ, Shaw PJ. Physical activity as an exogenous risk factor in motor neuron disease (MND): a review of the evidence. Amyotroph Lateral Scler 2009;10:191-204.

39. Huisman $\mathrm{MH}$, de Jong SW, van Doormaal PT, et al. Population based epidemiology of amyotrophic lateral sclerosis using capture-recapture methodology. J Neurol Neurosurg Psychiatry 2011;82:1165-70
40. Mattsson P, Lonnstedt I, Nygren I, et al. Physical fitness, but not muscle strength, is a risk factor for death in amyotrophic lateral sclerosis at an early age. J Neurol Neurosurg Psychiatry 2012:83:390-4.

41. Armon C. Sports and trauma in amyotrophic lateral sclerosis revisited. J Neurol Sci 2007;262:45-53.

42. Armon C. An evidence-based medicine approach to the evaluation of the role of exogenous risk factors in sporadic amyotrophic latera sclerosis. Neuroepidemiology 2003;22:217-28.

43. Hamidou B, Couratier P, Besancon C, et al. Epidemiological evidence that physical activity is not a risk factor for ALS. Eur $J$ Epidemiol 2014;29:459-75.

44. Chio A, Benzi G, Dossena M, et al. Severely increased risk of amyotrophic lateral sclerosis among Italian professional football players. Brain 2005;128(Pt 3):472-6.

45. Belli S, Vanacore N. Proportionate mortality of Italian soccer players: is amyotrophic lateral sclerosis an occupational disease? Eur J Epidemiol 2005;20:237-42.

46. Abel EL. Football increases the risk for Lou Gehrig's disease, amyotrophic lateral sclerosis. Percept Mot Skills 2007;104(3 Pt 2):1251-4.

47. Scarmeas N, Shih T, Stern $\mathrm{Y}$, et al. Premorbid weight, body mass, and varsity athletics in ALS. Neurology 2002;59:773-5.

48. Trojsi F, Sagnelli A, Vanacore N, et al. Clinical features and lifestyle of patients with amyotrophic lateral sclerosis in Campania: brief overview of an Italian database. Ann Ist Super Sanita 2012;48:287-91.

49. Vanacore N, Binazzi A, Bottazzi M, et al. Amyotrophic lateral sclerosis in an Italian professional soccer player. Parkinsonism Relat Disord 2006;12:327-9.

50. Mulder DW, Kurland LT. Motor neuron disease: epidemiologic studies. Adv Exp Med Biol 1987;209:325-32.

51. Kurland LT, Mulder DW. Epidemiologic investigations of amyotrophic lateral sclerosis. I. Preliminary report on geographic distribution and special reference to the Mariana Islands, including clinical and pathologic observations. Neurology 1954;4:438-48.

52. Reed D, Labarthe D, Chen KM, et al. A cohort study of amyotrophic lateral sclerosis and parkinsonism-dementia on Guam and Rota. Am J Epidemiol 1987;125:92-100.

53. Vega A, Bell EA. $\alpha$-amino- $\beta$-methylaminopropionic acid, a new amino acid from seeds of Cycas circinalis. Phytochemistry 1967;6:759-62.

54. Banack SA, Cox PA. Biomagnification of cycad neurotoxins in flying foxes: implications for ALS-PDC in Guam. Neurology 2003;61:387-9.

55. Murch SJ, Cox PA, Banack SA. A mechanism for slow release of biomagnified cyanobacterial neurotoxins and neurodegenerative disease in Guam. Proc Natl Acad Sci USA 2004;101:12228-31.

56. Cox PA, Banack SA, Murch SJ. Biomagnification of cyanobacterial neurotoxins and neurodegenerative disease among the Chamorro people of Guam. Proc Natl Acad Sci USA 2003;100:13380-3.

57. Banack SA, Murch SJ, Cox PA. Neurotoxic flying foxes as dietary items for the Chamorro people, Marianas Islands. J Ethnopharmacol 2006;106:97-104.

58. Duncan MW, Steele JC, Kopin IJ, et al. 2-Amino-3-(methylamino)propanoic acid (BMAA) in cycad flour: an unlikely cause of amyotrophic lateral sclerosis and parkinsonism-dementia of Guam. Neurology 1990;40:767-72.

59. Murch SJ, Cox PA, Banack SA, et al. Occurrence of betamethylamino-I-alanine (BMAA) in ALS/PDC patients from Guam. Acta Neurol Scand 2004;110:267-9.

60. Rao SD, Banack SA, Cox PA, et al. BMAA selectively injures motor neurons via AMPA/kainate receptor activation. Exp Neurol 2006;201:244-52.

61. Spencer PS, Nunn PB, Hugon J, et al. Motorneurone disease on Guam: possible role of a food neurotoxin. Lancet 1986;1:965.

62. Spencer PS, Nunn PB, Hugon J, et al. Guam amyotrophic lateral sclerosis-parkinsonism-dementia linked to a plant excitant neurotoxin. Science 1987;237:517-22.

63. de Munck E, Munoz-Saez E, Miguel BG, et al. beta-Nmethylamino-l-alanine causes neurological and pathological phenotypes mimicking Amyotrophic Lateral Sclerosis (ALS): the first step towards an experimental model for sporadic ALS. Environ Toxicol Pharmacol 2013;36:243-55.

64. de Munck E, Munoz-Saez E, Antonio MT, et al. Effect of beta-Nmethylamino-L-alanine on oxidative stress of liver and kidney in rat. Environ Toxicol Pharmacol 2013;35:193-9.

65. Engskog MK, Karlsson O, Haglof J, et al. The cyanobacterial amino acid beta-N-methylamino-l-alanine perturbs the intermediary metabolism in neonatal rats. Toxicology 2013;312:6-11. 
66. Banack SA, Johnson HE, Cheng R, et al. Production of the neurotoxin BMAA by a marine cyanobacterium. Mar Drugs 2007;5:180-96.

67. Cox PA, Banack SA, Murch SJ, et al. Diverse taxa of cyanobacteria produce beta-N-methylamino-L-alanine, a neurotoxic amino acid. Proc Natl Acad Sci USA 2005;102:5074-8.

68. Pablo J, Banack SA, Cox PA, et al. Cyanobacterial neurotoxin BMAA in ALS and Alzheimer's disease. Acta Neurol Scand 2009:120:216-25.

69. Dunlop RA, Cox PA, Banack SA, et al. The non-protein amino acid BMAA is misincorporated into human proteins in place of L-serine causing protein misfolding and aggregation. PLOS ONE 2013;8: e75376.

70. Karlsson O, Jiang $\mathrm{L}$, Andersson $\mathrm{M}$, et al. Protein association of the neurotoxin and non-protein amino acid BMAA (beta- $\mathrm{N}$ methylamino-l-alanine) in the liver and brain following neonatal administration in rats. Toxicol Lett 2014;226:1-5.

71. Vessey JK. Plant growth promoting rhizobacteria as biofertilizers. Plant Soil 2003;255:571-86.

72. Johnson HE, King SR, Banack SA, et al. Cyanobacteria (Nostoc commune) used as a dietary item in the Peruvian highlands produce the neurotoxic amino acid BMAA. J Ethnopharmacol 2008;118:159-65.

73. Roney BR, Renhui L, Banack SA, et al. Consumption of fa cai Nostoc soup: a potential for BMAA exposure from Nostoc cyanobacteria in China? Amyotroph Lateral Scler 2009;10(Suppl 2):44-9.

74. Jiang L, Eriksson J, Lage S, et al. Diatoms: a novel source for the neurotoxin BMAA in aquatic environments. PLOS ONE 2014;9: e84578.

75. Jonasson S, Eriksson J, Berntzon L, et al. Transfer of a cyanobacterial neurotoxin within a temperate aquatic ecosystem suggests pathways for human exposure. Proc Natl Acad Sci USA 2010;107:9252-7.

76. Esterhuizen M, Pflugmacher S, Downing TG. $\beta$-N-Methylamino-Lalanine (BMAA) uptake by the aquatic macrophyte Ceratophyllum demersum. Ecotoxicol Environ Saf 2011;74:74-7.

77. Cox PA, Sacks OW. Cycad neurotoxins, consumption of flying foxes, and ALS-PDC disease in Guam. Neurology 2002;58:956-9.

78. Markensten H, Moore K, Persson I. Simulated lake phytoplankton composition shifts toward cyanobacteria dominance in a future warmer climate. Ecol Appl 2010;20:752-67.

79. Paerl HW, Huisman J. Climate change: a catalyst for global expansion of harmful cyanobacterial blooms. Environ Microbiol Rep 2009;1:27-37

80. Cadel-Six S, Peyraud-Thomas C, Brient L, et al. Different genotypes of anatoxin-producing cyanobacteria coexist in the Tarn River, France. Appl Environ Microbiol 2007;73:7605-14.

81. Gugger M, Lenoir S, Berger C, et al. First report in a river in France of the benthic cyanobacterium Phormidium favosum producing anatoxin-a associated with dog neurotoxicosis. Toxicon 2005:45:919-28.

82. Pitois $\mathrm{F}$, Thomas $\mathrm{O}$, Thoraval $\mathrm{I}$, et al. Learning from 8 years of regional cyanobacteria observation in Brittany in view of sanitary survey improvement. Environ Int 2014;62:113-18.

83. Pobel D, Robin J, Humbert JF. Influence of sampling strategies on the monitoring of cyanobacteria in shallow lakes: lessons from a case study in France. Water Res 2011;45:1005-14.

84. Masseret E, Banack S, Boumediene F, et al. Dietary BMAA exposure in an amyotrophic lateral sclerosis cluster from southern France. PLOS ONE 2013;8:e83406.

85. Delzor A, Marin B, Boumediene F, et al. BMAALS: a French national project searching for a link between amyotrophic lateral sclerosis and the neurotoxic amino acid L-BMAA. Amyotroph Lateral Scler Frontotemporal Degener 2014;15:155-6.

86. Duboudin C, Lozach J, Harvey M. Cyanobacteria and cyanotoxins in surface water: a large scale statistical study in France. Epidemiology 2006;17:S502.

87. Hoeger SJ, Hitzfeld BC, Dietrich DR. Occurrence and elimination of cyanobacterial toxins in drinking water treatment plants. Toxicol Appl Pharmacol 2005;203:231-42.

88. Metcalf JS, Banack SA, Lindsay J, et al. Co-occurrence of beta-Nmethylamino-L-alanine, a neurotoxic amino acid with other cyanobacterial toxins in British waterbodies, 1990-2004. Environ Microbiol 2008;10:702-8.

89. Torbick N, Hession S, Stommel E, et al. Mapping amyotrophic lateral sclerosis lake risk factors across northern New England. Int J Health Geogr 2014;13:1.

90. Field NC, Metcalf JS, Caller TA, et al. Linking $\beta$-methylamino-Lalanine exposure to sporadic amyotrophic lateral sclerosis in Annapolis, MD. Toxicon 2013;70:179-83.
91. Brand LE, Pablo J, Compton A, et al. Cyanobacterial Blooms and the Occurrence of the neurotoxin beta-N-methylamino-L-alanine (BMAA) in South Florida Aquatic Food Webs. Harmful Algae 2010;9:620-35.

92. Mondo K, Hammerschlag N, Basile M, et al. Cyanobacterial neurotoxin $\beta$-N-methylamino-L-alanine (BMAA) in shark fins. Mar Drugs 2012;10:509-20.

93. Al-Sammak MA, Hoagland KD, Cassada D, et al. Co-occurrence of the cyanotoxins BMAA, DABA and anatoxin-a in Nebraska reservoirs, fish, and aquatic plants. Toxins (Basel) 2014;6:488-508

94. Heussner AH, Mazija L, Fastner J, et al. Toxin content and cytotoxicity of algal dietary supplements. Toxicol Appl Pharmacol 2012;265:263-71.

95. Rellan S, Osswald J, Saker M, et al. First detection of anatoxin-a in human and animal dietary supplements containing cyanobacteria. Food Chem Toxicol 2009;47:2189-95.

96. Cheng YS, Zhou Y, Irvin CM, et al. Characterization of aerosols containing microcystin. Mar Drugs 2007;5:136-50.

97. Cox PA, Richer R, Metcalf JS, et al. Cyanobacteria and BMAA exposure from desert dust: a possible link to sporadic ALS among Gulf War veterans. Amyotroph Lateral Scler 2009;10(Suppl 2):109-17.

98. Sharma NK, Singh S. Differential aerosolization of algal and cyanobacterial particles in the atmosphere. Indian J Microbiol 2010;50:468-73

99. Stommel EW, Field NC, Caller TA. Aerosolization of cyanobacteria as a risk factor for amyotrophic lateral sclerosis. Med Hypotheses 2013;80:142-5.

100. Marin B, Hamidou B, Couratier P, et al. Population-based epidemiology of amyotrophic lateral sclerosis (ALS) in an ageing Europe - the French register of ALS in Limousin (FRALim register). Eur J Neurol 2014. doi:10.1111/ene12474.

101. Brooks BR, Miller RG, Swash M, et al. El Escorial revisited: revised criteria for the diagnosis of amyotrophic lateral sclerosis. Amyotroph Lateral Scler Other Motor Neuron Disord 2000;1:293-9.

102. Brooks BR. El Escorial world federation of neurology criteria for the diagnosis of amyotrophic lateral sclerosis. Subcommittee on motor neuron diseases/amyotrophic lateral sclerosis of the world federation of neurology research group on neuromuscular diseases and the El Escorial "clinical limits of amyotrophic lateral sclerosis" workshop contributors. J Neurol Sci 1994;124(Suppl):96-107.

103. Great Lakes ALS Study Group. A comparison of muscle strength testing techniques in amyotrophic lateral sclerosis. Neurology 2003;61:1503-7.

104. Cedarbaum JM, Stambler N, Malta E, et al. The ALSFRS-R: a revised ALS functional rating scale that incorporates assessments of respiratory function. BDNF ALS Study Group (Phase III). J Neurol Sci 1999;169:13-21.

105. Gallay A, Nardone A, Vaillant V, et al. [The capture-recapture applied to epidemiology: principles, limits and application]. Rev Epidemiol Sante Publique 2002;50:219-32.

106. Hook EB, Regal RR. Capture-recapture methods in epidemiology: methods and limitations. Epidemiol Rev 1995;17:243-64.

107. Knox EG. Detection of clusters. London: Small Area Health Statistics Unit, 1989.

108. Elliott P, Wartenberg D. Spatial epidemiology: current approaches and future challenges. Environ Health Perspect 2004;112:998-1006.

109. Neutra RR. Counterpoint from a cluster buster. Am J Epidemio 1990;132:1-8.

110. Rothman KJ. A sobering start for the cluster busters' conference. Am J Epidemiol 1990;132(1 Suppl):S6-13.

111. Uccelli R, Binazzi A, Altavista $P$, et al. Geographic distribution of amyotrophic lateral sclerosis through motor neuron disease mortality data. Eur J Epidemiol 2007;22:781-90.

112. Turabelidze G, Zhu BP, Schootman M, et al. An epidemiologic investigation of amyotrophic lateral sclerosis in Jefferson County, Missouri, 1998-2002. Neurotoxicology 2008;29:81-6.

113. Doi $\mathrm{Y}$, Yokoyama T, Tango $\mathrm{T}$, et al. Temporal trends and geographic clusters of mortality from amyotrophic lateral sclerosis in Japan, 1995-2004. J Neurol Sci 2010;298:78-84.

114. Foy RH, Gibson CE, Smith RV. The influence of daylength, light intensity and temperature on the growth rates of planktonic bluegreen algae. BR Phycol J 1976;11:151-63.

115. Mischke U. Cyanobacteria associations in shallow polytrophic lakes: influence of environmental factors. Acta Oecologica Int $J$ Ecol 2003;24:S11-23.

116. Reichwaldt ES, Ghadouani A. Effects of rainfall patterns on toxic cyanobacterial blooms in a changing climate: between simplistic scenarios and complex dynamics. Water Res 2012;46:1372-93.

117. Shapiro J. Blue-green dominance in lakes: the role and management significance of $\mathrm{pH}$ and $\mathrm{CO}_{2}$. Int Rev Ges Hydrobiol 1984;69:765-80. 
118. Gorham E, Lund JWG, Sanger JE, et al. Some relationships between algal standing crop, water chemistry and sediment chemistry in the English lakes. Limnol Oceanogr 1974;19:601-17.

119. Dokulil MT, Teubner K. Cyanobacterial dominance in lakes. Hydrobiologia 2000;438:1-12.

120. Downing JA, Watson SB, McCauley E. Predicting cyanobacteria dominance in lakes. Can J Fish Aquat Sci 2001;58:1905-8.

121. Reynolds CS, Petersen AC. The distribution of planktonic cyanobacteria in Irish lake in relation to their trophic states. Hydrobiologia 2000;424:91-9.

122. Schindler DW, Hecky RE, Findlay DL, et al. Eutrophication of lakes cannot be controlled by reducing nitrogen input: results of a 37year whole-ecosystem experiment. Proc Natl Acad Sci USA 2008;105:11254-8.

123. Wilhelm SW. Ecology of iron-limited cyanobacteria: a review of physiological responses and implications for aquatic systems. Aquatic Microbial Ecol 1995:9:295-303.

124. Brock TD. Evolutionary and ecological aspects of the cyanophytes. Oxford: Blackwell Scientific Publications, 1973.

125. Carvalho L, Miller nee Ferguson CA, Scott EM, et al. Cyanobacterial blooms: statistical models describing risk factors for national-scale lake assessment and lake management. Sci Total Environ 2011:409:5353-8.

126. Brient $L$, Lengronne $M$, Bertrand $E$, et al. A phycocyanin probe as a tool for monitoring cyanobacteria in freshwater bodies. $J$ Environ Monit 2008;10:248-55.

127. Bradley WG, Borenstein AR, Nelson LM, et al. Is exposure to cyanobacteria an environmental risk factor for amyotrophic lateral sclerosis and other neurodegenerative diseases? Amyotroph Lateral Scler Frontotemporal Degener 2013;14:325-33.

128. Fang F, Quinlan $\mathrm{P}, \mathrm{Ye} \mathrm{W}$, et al. Workplace exposures and the risk of amyotrophic lateral sclerosis. Environ Health Perspect 2009;117:1387-92.

129. Weisskopf MG, McCullough ML, Morozova N, et al. Prospective study of occupation and amyotrophic lateral sclerosis mortality. Am J Epidemiol 2005;162:1146-52.

130. Furby A, Beauvais K, Kolev I, et al. Rural environment and risk factors of amyotrophic lateral sclerosis: a case-control study. J Neurol 2010;257:792-8.

131. Pamphlett R, Rikard-Bell A. Different occupations associated with amyotrophic lateral sclerosis: is diesel exhaust the link? PLoS ONE 2013;8:e80993.

132. Garruto RM, Gajdusek C, Chen KM. Amyotrophic lateral sclerosis among Chamorro migrants from Guam. Ann Neurol 1980;8:612-19.

133. Garruto RM, Gajdusek DC, Chen KM. Amyotrophic lateral sclerosis and parkinsonism-dementia among Filipino migrants to Guam. Ann Neurol 1981;10:341-50.

134. Combes A, El Abdellaoui S, Sarazin C, et al. Validation of the analytical procedure for the determination of the neurotoxin $\beta-\mathrm{N}$ methylamino-L-alanine in complex environmental samples. Anal Chim Acta 2013;771:42-9.

135. Byers T, Marshall J, Anthony $\mathrm{E}$, et al. The reliability of dietary history from the distant past. Am J Epidemiol 1987;125:999-1011.

136. Lindsted KD, Kuzma JW. Long-term (24-year) recall reliability in cancer cases and controls using a 21-item food frequency questionnaire. Nutr Cancer 1989;12:135-49.

137. Lindsted KD, Kuzma JW. Reliability of eight-year diet recall in cancer cases and controls. Epidemiology 1990;1:392-401.

138. Sobell J, Block G, Koslowe P, et al. Validation of a retrospective questionnaire assessing diet $10-15$ years ago. Am J Epidemiol 1989;130:173-87.

139. Wu ML, Whittemore AS, Jung DL. Errors in reported dietary intakes. II. Long-term recall. Am J Epidemiol 1988;128:1137-45.

140. Chavarro JE, Michels KB, Isaq S, et al. Validity of maternal recall of preschool diet after 43 years. Am J Epidemiol 2009;169:1148-57.

141. Karamyan VT, Speth RC. Animal models of BMAA neurotoxicity: a critical review. Life Sci 2008;82:233-46.

142. Vance JM, Ali S, Bradley WG, et al. Gene-environment interactions in Parkinson's disease and other forms of parkinsonism. Neurotoxicology 2010;31:598-602.

143. Perry TL, Bergeron C, Biro AJ, et al. Beta-N-methylamino-Lalanine. Chronic oral administration is not neurotoxic to mice. J Neurol Sci 1989;94:173-80.

144. Cruz-Aguado R, Winkler D, Shaw CA. Lack of behavioral and neuropathological effects of dietary beta-methylamino-L-alanine (BMAA) in mice. Pharmacol Biochem Behav 2006;84:294-9.

145. Polsky FI, Nunn PB, Bell EA. Distribution and toxicity of alphaamino-beta-methylaminopropionic acid. Fed Proc 1972;31:1473-5.

146. Smith SE, Meldrum BS. Receptor site specificity for the acute effects of beta-N-methylamino-alanine in mice. Eur $J$ Pharmacol 1990;187:131-4.
147. Ross SM, Spencer PS. Specific antagonism of behavioral action of "uncommon" amino acids linked to motor-system diseases. Synapse 1987;1:248-53.

148. Rakonczay Z, Matsuoka Y, Giacobini E. Effects of L-beta-Nmethylamino-L-alanine (L-BMAA) on the cortical cholinergic and glutamatergic systems of the rat. J Neurosci Res 1991;29:121-6.

149. Seawright AA, Brown AW, Nolan CC, et al. Selective degeneration of cerebellar cortical neurons caused by cycad neurotoxin, L-betamethylaminoalanine (L-BMAA), in rats. Neuropathol Appl Neurobiol 1990;16:153-69.

150. Matsuoka Y, Rakonczay Z, Giacobini E, et al. L-beta-methylaminoalanine-induced behavioral changes in rats. Pharmacol Biochem Behav 1993;44:727-34.

151. Chang YC, Chiu SJ, Kao KP. beta-N-methylamino-L-alanine (LBMAA) decreases brain glutamate receptor number and induces behavioral changes in rats. Chin J Physiol 1993;36:79-84.

152. Karlsson O, Berg C, Brittebo EB, et al. Retention of the cyanobacterial neurotoxin beta- $\mathrm{N}$-methylamino-I-alanine in melanin and neuromelanin-containing cells-a possible link between Parkinson-dementia complex and pigmentary retinopathy. Pigment Cell Melanoma Res 2009;22:120-30.

153. Bradley WG, Mash DC. Beyond Guam: the cyanobacteria/BMAA hypothesis of the cause of ALS and other neurodegenerative diseases. Amyotroph Lateral Scler 2009;10(Suppl 2):7-20.

154. Lobner D, Piana PM, Salous AK, et al. Beta-N-methylamino-Lalanine enhances neurotoxicity through multiple mechanisms. Neurobiol Dis 2007;25:360-6.

155. Cucchiaroni ML, Viscomi MT, Bernardi G, et al. Metabotropic glutamate receptor 1 mediates the electrophysiological and toxic actions of the cycad derivative beta-N-Methylamino-L-alanine on substantia nigra pars compacta DAergic neurons. J Neurosci 2010;30:5176-88.

156. Munoz-Saez E, de Munck E, Arahuetes RM, et al. beta-Nmethylamino-L-alanine induces changes in both GSK3 and TDP-43 in human neuroblastoma. J Toxicol Sci 2013;38:425-30.

157. Dewey CM, Cenik B, Sephton CF, et al. TDP-43 aggregation in neurodegeneration: are stress granules the key? Brain Res 2012:1462:16-25

158. Li G, Cai F, Yan W, et al. A proteomic analysis of MCLR-induced neurotoxicity: implications for Alzheimer's disease. Toxicol Sci 2012;127:485-95.

159. Metcalf JS, Codd GA. Cyanobacteria, neurotoxins and water resources: are there implications for human neurodegenerative disease? Amyotroph Lateral Scler 2009;10(Suppl 2):74-8.

160. Faassen EJ, Gillissen F, Lurling M. A comparative study on three analytical methods for the determination of the neurotoxin BMAA in cyanobacteria. PLoS ONE 2012;7:e36667.

161. Kruger T, Monch B, Oppenhauser S, et al. LC-MS/MS determination of the isomeric neurotoxins BMAA (beta- $\mathrm{N}$ methylamino-L-alanine) and DAB (2,4-diaminobutyric acid) in cyanobacteria and seeds of Cycas revoluta and Lathyrus latifolius. Toxicon 2010;55:547-57.

162. Banack SA, Metcalf JS, Spacil Z, et al. Distinguishing the cyanobacterial neurotoxin beta- $\mathrm{N}$-methylamino-L-alanine (BMAA) from other diamino acids. Toxicon 2011;57:730-8.

163. Montine TJ, Li K, Perl DP, et al. Lack of beta-methylamino-l-alanine in brain from controls, AD, or Chamorros with PDC. Neurology 2005;65:768-9.

164. Snyder LR, Cruz-Aguado R, Sadilek M, et al. Lack of cerebral BMAA in human cerebral cortex. Neurology 2009;72:1360-1.

165. Snyder LR, Cruz-Aguado R, Sadilek M, et al. Parkinson-dementia complex and development of a new stable isotope dilution assay for BMAA detection in tissue. Toxicol Appl Pharmacol 2009;240:180-8.

166. Snyder LR, Hoggard JC, Montine TJ, et al. Development and application of a comprehensive two-dimensional gas chromatography with time-of-flight mass spectrometry method for the analysis of L-beta-methylamino-alanine in human tissue. J Chromatogr A 2010;1217:4639-47.

167. Jiang $\mathrm{L}$, Johnston $\mathrm{E}$, Aberg $\mathrm{KM}$, et al. Strategy for quantifying trace levels of BMAA in cyanobacteria by LC/MS/MS. Anal Bioanal Chem 2013;405:1283-92.

168. Kisby GE, Roy DN, Spencer PS. Determination of beta-Nmethylamino-L-alanine (BMAA) in plant (Cycas circinalis L.) and animal tissue by precolumn derivatization with 9-fluorenylmethyl chloroformate (FMOC) and reversed-phase high-performance liquid chromatography. J Neurosci Methods 1988;26:45-54.

169. McElhiney J, Lawton LA, Leifert C. Investigations into the inhibitory effects of microcystins on plant growth, and the toxicity of plant tissues following exposure. Toxicon 2001;39:1411-20. 
170. Glover WB, Liberto CM, McNeil WS, et al. Reactivity of betamethylamino-L-alanine in complex sample matrixes complicating detection and quantification by mass spectrometry. Anal Chem 2012;84:7946-53.

171. Karlsson O, Lindquist NG, Brittebo EB, et al. Selective brain uptake and behavioral effects of the cyanobacterial toxin BMAA (beta-Nmethylamino-L-alanine) following neonatal administration to rodents. Toxicol Sci 2009;109:286-95.

172. Karlsson O, Roman E, Brittebo EB. Long-term cognitive impairments in adult rats treated neonatally with beta-Nmethylamino-L-alanine. Toxicol Sci 2009;112:185-95.

173. Karlsson O, Roman E, Berg AL, et al. Early hippocampal cell death, and late learning and memory deficits in rats exposed to the environmental toxin BMAA (beta-N-methylamino-L-alanine) during the neonatal period. Behav Brain Res 2011;219:310-20.

174. Karlsson O, Berg AL, Lindstrom AK, et al. Neonatal exposure to the cyanobacterial toxin BMAA induces changes in protein expression and neurodegeneration in adult hippocampus. Toxicol Sci 2012;130:391-404.
175. Andersson M, Karlsson O, Bergstrom U, et al. Maternal transfer of the cyanobacterial neurotoxin beta-N-methylamino-L-alanine (BMAA) via milk to suckling offspring. PLOS ONE 2013;8:e78133.

176. Chestnut BA, Chang Q, Price A, et al. Epigenetic regulation of motor neuron cell death through DNA methylation. $J$ Neurosci 2011;31:16619-36.

177. Martin LJ, Wong M. Aberrant regulation of DNA methylation in amyotrophic lateral sclerosis: a new target of disease mechanisms. Neurotherapeutics 2013;10:722-33.

178. Callaghan B, Feldman D, Gruis K, et al. The association of exposure to lead, mercury, and selenium and the development of amyotrophic lateral sclerosis and the epigenetic implications. Neurodegener Dis 2011;8:1-8.

179. Pilsner JR, Hu H, Ettinger A, et al. Influence of prenatal lead exposure on genomic methylation of cord blood DNA. Environ Health Perspect 2009;117:1466-71.

180. Morahan JM, Yu B, Trent RJ, et al. Genetic susceptibility to environmental toxicants in ALS. Am J Med Genet B Neuropsychiatr Genet 2007;144B:885-90. 